\title{
Re Routing of Links Associated Purchase of Low Cost Products Availabel in Online Shopping Websites
}

\author{
C. Archanapriya, S. Barani Chelvi B.Venakata Srilatha
}

\begin{abstract}
Illuminating assessment is used in this examination since it will ensure the minimization of reason and expansion of resolute nature of data accumulated. For this assessment sorted out survey was used. Hypnotizing investigation is essentially drawn in with studies and truth finding enquires of different sorts. Methodical studies are most useful for testing a speculated connection between two factors. The essential inspiration driving precise research is to intuition or acting from apperception of the parts and interrelations of a subject. The test size builds up 100 respondents.The study is driven among the online customers in TAMBARM..
\end{abstract}

Keywords: Hypnotizing investigation Methodical studies

\section{INTRODUCTION}

The term advertising for the most part alludes a spot where purchasers and dealers get together. The importance and nature of advertising has experienced progressive changes extra time. On the closer perception on chronicled assessment of market, various phases of exchange can without much of a stretch be goal, the last stage being the time of internet shopping. After a long time improvement of web, this snappy extended web customers and especially speed interest change, and same new development also has been made and used for web working up, those lead to firm can progress and update pictures of thing and organizations through webpage. Thusly definite item data and improved help pulls in an ever increasing number of individuals change their purchaser conduct from the customary mode to more depend on web shopping.[1]-[4]

\section{LITERATURE REVIEW}

$\square$ Anastasia (1982) mulled over on the - employment of social characteristics on online business: With the issue of social and client from different social establishments may

Revised Manuscript Received on December 30, 2019.

C. Archanapriya, Assistant Professor, Department of Science \& Humanities,Bharath Institution Of Higher Education And Research TamilNadu ,India Email: Archanapriya854@gmail.com

S. Barani Chelvi, Assistant Professor, Department of Science \& Humanities,Bharath Institution Of Higher Education And Research TamilNadu ,India Email baranikarthi1629@gmail.com

Venkata Srilatha Assistant Professor, Department of Science \& Humanities,Bharath Institution Of Higher Education And Research TamilNadu ,India Email: bvsrilatha27@gmail.com survey and see a comparative situation particularly for web shopping.

$\square$ Spiller, P., Lohse, G. (1997) completed wear down "A Classification of Internet Retail Stores". Their work shows a plan of on-line retail stores subject to settlement trial of 137 Internet retail stores. Their assessment perceived five differing on-line store structure procedures: Super Stores, Promotional Stores, Plain Sales Stores, One Page Stores and Product Listings. They differentiate generally to the extent the store's size, the measure of extra information and canapés, and the interface arrangement including consistency, page lengths, picture sizes and course capacities[5]-[9]

\section{OBJECTIVES OF THE STUDY}

To study the kind of care on customers legal rights in web shopping

$\square$ To know the issues of using electronic shopping.

\section{NEED OF THE STUDY}

From this assessment experts found why customers deferral or waver to choose decision for shopping on the web. Examiner analyze the various factors that effect customer to shop from online. Find the reasons and gave the proposition for the issues looked by the customers. In like manner find the ways to deal with rout the issues looked by customers. Found, what are the blackmail activities done on web shopping.Hypothesis Test: 1-Legal terms consider while web based shopping [10]-[14]

\begin{tabular}{|c|c|c|c|c|c|}
\hline & N & Minimum & Maximum & Mean & Std. Deviation \\
\hline Price and payments & 100 & 2 & 5 & 4.65 & .730 \\
Privacy policies & 100 & 1 & 5 & 3.88 & .913 \\
Payment Details & 100 & 1 & 5 & 4.23 & .815 \\
Website Policies & 100 & 1 & 5 & 3.49 & 1.000 \\
Warrantee policies & 100 & 1 & 5 & 4.00 & 1.073 \\
Guarantee policies & 100 & 1 & 5 & 4.04 & 1.109 \\
Valid N (listricise) & 100 & & & & \\
\hline
\end{tabular}

\section{RESULTS}

The above table shows the descriptive statistics of legal terms considered by the customer in online shopping. The legal terms on price and payments, payment details have the highest mean value of 4.65 and 4.23. And privacy policy has the least mean value of 3.88 .

Hypothesis Test: 2

Problems faced during online shopping [15]-[19] 


\begin{tabular}{|c|c|c|c|c|c|}
\hline & N & Minimum & Maximum & Mean & Std. Deviation \\
\hline Delivery problem & 100 & 1 & 5 & 3.65 & 1.104 \\
Products are not as same as & 100 & 2 & 5 & 4.17 & .829 \\
photos & 100 & 2 & 5 & 3.75 & .989 \\
Poor quality & 100 & 1 & 5 & 3.45 & 1.038 \\
Additional charges & 100 & 1 & 5 & 3.32 & 1.053 \\
Payments option & 100 & 5 & 3.44 & 1.085 \\
Communication problem & 100 & 1 & 5 & \\
Difficulties in E-payments & 100 & 1 & 5 & 3.07 & 1.075 \\
Securities problem & 100 & 1 & 5 & 3.07 & .956 \\
Problems in replace and & 100 & 1 & 5 & 3.67 & 1.092 \\
refund & 100 & & & & \\
Valid N (listyises) & 100 & & & & \\
\hline
\end{tabular}

\section{FINDINGS:}

The above table shows the unmistakable measurements of issues looked during web based shopping. Issues, for example, Delivery issue, Products are not as same as photographs, Poor quality having the high mean worth and issues, for example, Difficulties in E-installments, Securities issue, Problems in supplant and discount. [21]-[25]

\section{SUGGESTIONS}

$\square$ There is a relationship among capability and mindfulness on lawful rights in web based shopping

$\square$ There is a relationship among capability and mindfulness on lawful rights in web based shopping

\section{CONCLUSION:-}

This investigation shows that web shopping in Chennai has an incredibly breathtaking in India. With the use of web, the customer can shop wherever, anything and at whatever point with basic and safe portions choices. Purchasers can do connection shopping between things, similarly as, online stores. Different buyers lean toward exchanging and pick the buys after physical assessment of the items. The whole system can go from a couple of hours to weeks subordinate upon the thing, aggregate, quality and wellspring of procurement. Today there is radical change in the whole situation. Everything nowadays is Internet masterminded like Electronic Data Interchange, E-Mail, E-Business and E-Commerce

\section{REFERENCES}

1. Vasanthi, S. \& Rabiyathul Basariya, S. 2019, "Influence of value analysis and cross training in industry", International Journal of Engineering and Advanced Technology, vol. 8, no. 6, pp. 1810-1811.

2. Velvizhi, R., Sri Gowtham, S. \& Jeya Priya, D. 2019, "Examination of early feedbacks for effective product retailing on E-commerce websites", International Journal of Engineering and Advanced Technology, vol. 8, no. 6 Special Issue 2, pp. 703-706.

3. Anuradha, C., Pothumani, S. \& Kavitha, R. 2019, "A novel method towards E-commerce", International Journal of Engineering and Advanced Technology, vol. 8, no. 6 Special Issue 2, pp. 535-538.

4. Thomas, J. \& Rabiyathul Basariya, S. 2019, "A study on the issues of financial ratio analysis", Indian Journal of Public Health Research and Development, vol. 10, no. 3, pp. 1079-1081.

5. Ramachandran, S. \& Rabiyathul Basariya, S. 2019, "Online marketing - study on customer satisfaction and relationship", Indian Journal of
Public Health Research and Development, vol. 10, no. 3, pp 1072-1078.

6. Priya, R., Vinothini, G. \& Cor Jesu, C.D. 2019, "The mentor-protégé relationship for professional growth", Journal of Advanced Research in Dynamical and Control Systems, vol. 11, no. 9 Special Issue, pp. 1110-1119.

7. Jannifer Rani, N., Bina Pani, S. \& Nimisha, N.S. 2019, "A study on money back polices available in LIC", Journal of Advanced Research in Dynamical and Control Systems, vol. 11, no. 9 Special Issue, pp. 833-839.

8. Saillaja, V., Jhansi Rani, K. \& Catherine, R. 2019, "Global marketing management planning and organization", Journal of Advanced Research in Dynamical and Control Systems, vol. 11, no. 9 Special Issue, pp. 489-493.

9. Saillaja, V., Jhansi Rani, K. \& Catherine, R. 2019, "The new phase of marketing information system", Journal of Advanced Research in Dynamical and Control Systems, vol. 11, no. 9 Special Issue, pp. 482-488.

10. Thoufiqulla \& Raju, D.V. 2019, "Perception of indian investor towards investment in mutual funds with special reference to mip funds", Journal of Advanced Research in Dynamical and Control Systems, vol. 11, no. 5, pp. 177-183.

11. Jasmine, K.R.M. \& Basariya, S.R. 2018, "A study on the customers benefits on mutual funds", International Journal of Civil Engineering and Technology, vol. 9, no. 4, pp. 45-48.

12. Vasanthi, S. \& Basariya, S.R. 2019, "Pros and cons of on the job training versus off the job training", International Journal of Scientific and Technology Research, vol. 8, no. 10, pp. 671-674.

13. Pavithra, J. \& Ganesan, M. 2016, "A study on awareness and impact of micro-financial schemes", International Journal of Applied Business and Economic Research, vol. 14, no. 8, pp. 5449-5460.

14. Pavithra, J., Dilli Babu, P. \& Ambuli, T.V. 2014, "A study on budgetary control at Maruti Service Masters, Chennai", International Journal of Applied Business and Economic Research, vol. 12, no. 2, pp. 151-161.

15. Gunaraja, T.M. \& Venkatrama Raju, D. 2018, "Determining factors of organisational climate with reference to leadership styles", International Journal of Mechanical Engineering and Technology, vol. 9, no. 9, pp. 1327-1332.

16. Gunaraja, T.M. \& Venkatrama Raju, D. 2018, "The role of job satisfaction and training of employees in determining organisational climate of a selected industry", International Journal of Civil Engineering and Technology, vol. 9, no. 8, pp. 1266-1269.

17. Aarathy, T.S. \& Raju, D.V. 2018, "Performance appraisal and its effects on employees with respect to it sector in Chennai city", International Journal of Civil Engineering and Technology, vol. 9, no. 6, pp. 1535-1538.

18. Aarathy, T.S. \& Raju, D.V. 2018, "Employee perception towards performance appraisal system in IT sector", International Journal of Mechanical Engineering and Technology, vol. 9, no. 5, pp. 131-135.

19. Porselvi, W., Jublee, D. \& Sivanesan, G. 2018, "A study on factors influencing adoption of technology and innovation in banking industry, tamilnadu, India", International Journal of Mechanical Engineering and Technology, vol. 9, no. 5, pp. 789-800.

20. Akessa, G.M. and Dhufera, A.G., 2015. Factors That Influences Students Academic Performance: A Case of Rift Valley University, Jimma, Ethiopia. Journal of Education and Practice, 6(22), pp.55-63.

21. Miller, G. and Shih, C.C., 1999. A faculty assessment of the academic rigor of on-and off-campus courses in agriculture. Journal of Agricultural Education, 40, pp.57-65.

22. Tsinidou, M., Gerogiannis, V. and Fitsilis, P., 2010. Evaluation of the factors that determine quality in higher education: an empirical study. Quality Assurance in education, 18(3), pp.227-244.

23. Farooq, M.S., Chaudhry, A.H., Shafiq, M. and Berhanu, G., 2011 Factors affecting students' quality of academic performance: a case of secondary school level. Journal of quality and technology management, 7(2), pp.1-14.

24. Fitsilis, P., Gerogiannis, V. and Anthopoulos, L., 2014. Ontologies for software project management: a review. Journal of Software Engineering and Applications, 7(13), p.1096.

25. Adams, J.D. and Jaffe, A.B., 1996. Bounding the effects of R\&D: an investigation using matched establishment-firm data(No. w5544). National bureau of economic research.

\section{AUTHORS PROFILE}

Published By:

Blue Eyes Intelligence Engineering \& Sciences Publication 
C. Archanapriya, Assistant Professor, Department of Science \& Humanities, Bharath Institution Of Higher Education And Research TamilNadu ,India

S. Barani Chelvi, Assistant Professor, Department of Science \& Humanities,Bharath Institution Of Higher Education And Research TamilNadu ,India

Venkata Srilatha Assistant Professor, Department of Science \& Humanities,Bharath Institution Of Higher Education And Research TamilNadu ,India 